\title{
Environmental Systems and Local Actors: Decentralizing Environmental Policy in Uganda
}

\author{
Peter Oosterveer - Bas Van Vliet
}

Received: 15 January 2009/Accepted: 17 December 2009/Published online: 19 January 2010

(C) The Author(s) 2010. This article is published with open access at Springerlink.com

\begin{abstract}
In Uganda, environmental and natural resource management is decentralized and has been the responsibility of local districts since 1996. This environmental management arrangement was part of a broader decentralization process and was intended to increase local ownership and improve environmental policy; however, its implementation has encountered several major challenges over the last decade. This article reviews some of the key structural problems facing decentralized environmental policy in this central African country and examines these issues within the wider framework of political decentralization. Tensions have arisen between technical staff and politicians, between various levels of governance, and between environmental and other policy domains. This review offers a critical reflection on the perspectives and limitations of decentralized environmental governance in Uganda. Our conclusions focus on the need to balance administrative staff and local politicians, the mainstreaming of local environmental policy, and the role of international donors.
\end{abstract}

Keywords Environmental governance .

Political decentralization · Uganda

The decentralization of environmental and natural resource management is often cited as a simple and attractive way to improve environmental policy. This view is based on the idea that most governments, particularly African governments, do not have the capacity at the central level to

P. Oosterveer $(\bowtie) \cdot$ B. Van Vliet

Wageningen University, Environmental Policy, P.O. Box 8130,

Wageningen 6700EW, The Netherlands

e-mail: peter.oosterveer@wur.nl effectively implement necessary environmental protection measures. This impediment leads to a continued degradation of soil, forest coverage, water quality, and biodiversity (UNEP 2002). Environmental management is thought to be more effective when local communities are given responsibility; these communities are supposedly better placed to manage their neighboring environment and natural resources.

Since the early 1990s, many countries have promoted decentralized environmental governance as part of a broader trend toward the decentralization of governmental responsibilities; this decentralization is designed to improve effectiveness, efficiency, transparency, and democracy. Uganda has been hailed as a positive example in Africa because of its radical shifting of responsibilities to the local (district) level, including considerable human and financial resources. The decentralization of environmental and natural resource management has become a substantial and integral part of this policy. But has this led to real improvements?

Studies of decentralized environmental governance suggest that different programs in Africa have failed to effectively deliver on their promises both to the community and to the environment (Blaikie 2006; Conyers 2007; Robinson 2007; Polidano and Hulme 1999). These disappointing results are at least partly attributed to the difficulties of improving environmental performance under the conditions of structural poverty and in situations where the local community is highly dependent on natural resources. However, other researchers point to the complex relationships among public administrators, political elites, and international donors who are involved in national and local politics (Andeweg 2006; Blaikie 2006; Mubeezi 2007). An examination of the extensive experience of decentralized environmental governance in Uganda may offer useful 
insights into the relevance of these explanations and help governments understand whether such difficulties can be overcome. Therefore, this article closely examines the recent political history of Uganda and asks to what extent this country has been able to improve its environmental and natural resource management through decentralization. The article draws on several sources: existing literature; two qualitative case studies completed by M.Sc. students that examine decentralized wetland management and environmental health policies in different districts of Uganda; three training workshops for District Environmental Officers (DEOs) in Uganda that were organized between 2005 and 2008; and several site visits to various regions of Uganda (Kampala, Mukono, Jinja, and Masaka).

We begin by taking a closer look at the broader debate on decentralization and environmental policy and then provide an overview of recent developments in Uganda. Next, we assess current practices in local environmental governance in Uganda. Finally, we conclude by discussing the limitations and perspectives of local environmental governance; we intend to identify the conditions under which local environmental and natural resource management can live up to the challenge of securing Uganda's rich resources for future generations.

\section{Decentralization and Environmental Policy}

Political decentralization became popular in the 1980s and continued to gain the support of many African governments in the 1990s. Despite its popularity, the precise definition of decentralization and the best model for its implementation remain unclear. Several concepts (deconcentration, delegation, and devolution [Dressler 2006]) have been used to describe the various approaches implemented in different countries, to explain their respective successes and failures, and to identify the most promising model. Because of the different conceptual frameworks applied, this debate has not produced a shared ideal model of decentralization.

For many scholars, decentralization should implement the objectives of the New Public Management School; this view focuses on a technocratic model intended to create more effective and efficient public service delivery (Kiragu 2002; Conyers 2007). Increased orientation toward clients in the operation of such services is sought through the "unbundling of vertically integrated bureaucracies into separate organizational or ownership forms with the aim of improving the efficiency and effectiveness of public goods and services" (Caulfield 2006, p. 17). The underlying assumption here is that specialized service delivery systems can function more effectively when they are not under the direct political control of a government ministry. Most
African governments were considered weak and unable to deliver the goods and services demanded by the different groups in society. The devolvement of administrative capacity and active involvement of stakeholders was therefore expected to address this weakness. These policy reforms were broadly supported by international donors who expected them to facilitate community participation and strengthen the demand side of the public service equation.

However, decentralization is not just a technocratic and administrative effort, but a political one as well. Some consider decentralization to be a process of democratization that redistributes power. In this view, decentralization gives stakeholders a greater role in decision-making, and this increased participation leads to better decisions which are more broadly supported. However, others analyze this as a dynamic political process in which centralization and decentralization are interactively constituted. The process does not simply involve "the distribution of the manifest powers of decision-making and the challenges involved in the (re)allocation of resources" (Berkhout 2005, p. 315), because power is relational and mediated through discourses (Foucault 1977). When analyzing processes of decentralization it is therefore essential to distinguish between the model and the outcome. The results of political decentralization are not necessarily determined by the selected model but, rather, by the interactions among the model, the implementation process, and the specific local and national dynamics through which decentralization is effected. These dynamics take place at three levels: the individual level, the institutional level, and the systemic level. At the individual level, local capacity is influenced by the values, culture, training, and attitudes of local government personnel, both elected officials and administrative staff. At the institutional level, the impact relates to local government structures, procedures, and operating rules, all of which frame and govern the activities of personnel. At the systemic level, local governance is affected by the policy and legal frameworks within which the local governments operate and by the rules and practices that govern the relations of local governmental authorities with other actors (Romeo 2003). These different dynamics exclude a simple focus on models of decentralization and require a more detailed analysis of impacts in practice. These general conclusions on the dynamics of decentralization are relevant for the case of environmental and natural resource management as well.

Although it is not necessarily the main reason for engaging in a process of decentralization, environmental and natural resource management seems to be an attractive domain for it. The decentralization of natural resource management in Africa is located at the intersection among good governance and democracy, development and poverty alleviation, and community-based resource management 
and local resource rights. Many environmentalists consider the local community to be the most appropriate custodian of environmental management since they "are better able to understand and intervene in environmental problems because they are 'closer' to both the problem and the solution" (Lane and McDonald 2005, p. 710), although this is also contested. These environmentalists define communities according to tight spatial boundaries of jurisdiction and responsibilities and see them as having distinct and integrated social structures and common interests. Hence, it is expected that the local ownership of natural resources as well as the administrative power to protect those resources will be more effective than traditional, centralized environmental policy. This focus on shared interest is expressed in the widespread engagement of communities in the implementation of Local Agenda 21 (Mehta 1996). In Africa, as UNEP (2002) claims, natural resources have been woven into the daily lives of many people. Particular traditional and cultural values among the diverse communities across the continent have guided the way people interact with their environment and how natural resources are used and managed. In many subregions, the people's relationship with natural resources remains strong, and traditional regulatory mechanisms are still in place that facilitate sensible resource use and conservation. Environmentalists often draw attention to these traditions to promote decentralization in sub-Saharan Africa (Woodhouse 1997). Decentralized environmental and natural resource management would allow local communities to be actively involved and to address their main environmental problems in ways that suit their local needs (Agrawal and Gibson 1999). Some observers regard the decentralization of environmental policy as even an "institutionalized form of community participation" (Ribot 2002).

Others, however, question this idealistic image of local communities. Larson and Soto (2008), for example, comment that the concept of community often assumes "a small and stable spatial unit, homogenous social structure, and shared norms" (228), while reality is often much more complex. Populations may be highly mobile, socially and economically differentiated and possess competing interests and values. The decentralization of environmental and natural resource management is therefore not only an administrative act, but also a political process involving a redistribution of power and resources (Larson and Soto 2008). However, when African governments initiate a process of decentralization in natural resource management, they tend to include the local level in such a way as to render it manageable in a uniform manner. This effectively requires local diversity to be "black-boxed" to make it possible to regulate what is a diverse and complex movement of people (and sometimes resources) through space and time (Blaikie 2006). As a consequence, despite the uniform approach used in the decentralization of environmental policy, in reality the outcomes may differ considerably between different local contexts. The results are therefore moderated by national political histories and cultures, by the specific dynamics involved in the interaction between national and local level politics, and by divisions of social class, ethnicity, and gender. As a result, both the extent of decentralization and its outcomes will vary from one context to another and from one natural resource to another (Bazaara 2003).

Undertaking such a radical public sector reform as the decentralization of environmental policy under the difficult circumstances prevailing in sub-Saharan Africa is complicated. State institutions dispose of limited financial and human resources, while slow (or even negative) economic growth and a high dependence on foreign aid complicate the context even further. These constraints are probably more pronounced at lower levels of government. We must therefore analyze the strengths and weaknesses of decentralized environmental governance; this article does so by assessing the experiences of Uganda, with a focus on the institutional and systemic levels.

Larson and Soto (2008) identified institutional configurations and balances of power that emerge in two key spheres during the decentralization process; they focused on interactions between central and local authorities and among local governments and other local actors involved in or affected by natural resource management. In our case study in Uganda, we distinguish between two interactions in the second configuration: the interactions between the local administrative staff and local politicians and those between local environmental and natural resource management and other local policy domains.

Three specific tensions are particularly important in decentralized environmental policymaking in Uganda and are addressed in the remainder of this article.

1. The tension between technical staff and locally elected officials who legitimately claim they represent their constituents. These constituents do not always support the introduction and implementation of environmental protection measures (Caulfield 2006).

2. The tension between different levels of government, particularly between the district level and the national level.

3. The tension between environmental and natural resource management and other policy domains such as health, education, agriculture, and economic development. Environmental considerations must become a part of mainstream local policies and must compete for limited financial resources.

Before addressing these tensions, we offer a brief introduction to the decentralization of environmental policy in Uganda. 


\section{The History of Environmental Policy Decentralization in Uganda}

In the 1980s, Uganda initiated efforts to strengthen local governments; the decentralization of natural resource management was included in a later stage of this process. Local governments were established in Uganda in the colonial era but the political system became more centralized after 1967. Between the early 1970s and the middle of the 1980s, Uganda went through a period of political turmoil that led to a dramatic decline in its political and economic performance. By the time the National Resistance Movement took state power in 1986, this process was reversed and national development, including the strengthening of local governments, was taken up more seriously. The main reforms were implemented in the 1980s and 1990s and were consolidated in a new constitution in 1995; these reforms were further detailed in the Local Governments Act of 1997. The decentralization process continues to this day through both large and small legal and administrative adaptations (Kisembo 2006).

Uganda's policy of decentralization is officially focused on empowering local populations via democratization, participation, accountability, responsibility, efficiency, and effectiveness (Nsibambi 1998). Institutionally, decentralization in Uganda is built on a hierarchical structure of local councils (LCs) that stretches from the village (LC1) through the parish (LC2), the subcounty (LC3), the county (LC4), and the district (LC5). These LCs have all been empowered through decentralization but the process has particularly affected the district and the sub-county levels; these levels are considered to be a part of local government, while the other levels are simply administrative units. The main political and administrative powers at the local level are vested in the district (LC5) and the governing body of the district is also directly elected by the population. The number of districts in Uganda has grown considerably over the years. From only 33 districts in 1986, the number grew to 45 in 1998, 56 in 2003, and to 80 by 2008. This growth has improved manageability, although with approximately 30 million inhabitants in Uganda, each district still includes approximately 360,000 inhabitants. On the other hand, this growing number of districts necessitated continuous administrative reorganization at the local level; this meant that more financial resources were spent on administrative tasks and development budgets thinned. In 2008, "75 of the 80 districts appealed for financial assistance from the central government after many had failed to meet their running costs" (The Independent magazine, Sept 5-Sept 11, 2008, p. 16).

The continuous growth in the number of districts can be explained by the social, cultural, economic, and political dynamics generated at the local level by decentralization.
For example, ethnic sentiments suppressed under the nation-building programs of the 1960s have resurfaced, so districts with more than one ethnic group tend to break up as political elites try to maximize benefits and minimize losses to their political power and wealth. In addition, political leaders from the ruling National Resistance Movement seeking to build their numerical strength before general elections encourage new districts in exchange for political support.

In the early phase of decentralization, local authorities could use the graduated tax they collected; in the 19992000 fiscal year, this tax contributed to $67 \%$ of the locally generated revenues (Iversen and others 2006). However, over the years these incomes declined, and during the presidential election of July 2005, the graduated tax was completely abolished by national politicians. This move stripped local authorities of their main local source of income. In effect, this decision was a major step back in the decentralization process. Although this has partly been repaired by a (temporary) Graduated Tax Compensation that allocates funds from the central government to local governments (Republic of Uganda 2008), local authorities now only control minor sources of self-generated revenue, including the fees and taxes that are levied, charged, collected, and appropriated as rents, rates, royalties, stamp duties, or fees on registration and licensing. These limited local financial resources and the restrictions attached to funding received from the central government limit the possible actions of decentralized governments.

\section{Decentralizing Natural Resource Management}

When the local governments were initially formalized in 1993, decentralization was seen not as a means of democratizing power over natural resource management but as a means of increasing revenue, promoting local development, and improving the effectiveness and legitimacy of the state. Decentralization was initiated by the National Resistance Movement leadership but pressure from international donors further accelerated the process. National authorities yielded to this pressure because they needed international recognition and financial support (Wetaaka Wadala 2007). It was only later that environmental issues entered this realm, again mainly due to pressure from foreign donors, including the World Bank. These international donors made decentralization a condition for the release of grants or loans to implement certain environment-related programs (Bazaara 2003). These donors justified their interference with the claim that "userbased natural resource management is the most reliable, cost-effective, and sustainable method for as long as the population is adequately educated and made aware of the importance and potential wealth of natural resources" 
(Odwedo 1995, p. 2). This approach was designed to shift responsibility for natural resource management away from the central government so that local authorities and communities would not only be seen as conduits for the implementation of national regulations. Decentralization thus not only shifted the responsibility for environmental planning and management to the districts but also was intended to ensure the presence of participatory planning and decision-making, transparency, accountability, and sustainability in the entire development process; this process became known as the "mainstreaming" of environmental and natural resource management (Odwedo 1995).

Despite its favorable climate and soil conditions, Uganda has a number of urgent environmental problems. According to reports from organizations like the MNR (1994) and National Environment Management Authority (NEMA 2007), these problems can be categorized into land, water, forest, and biodiversity issues. The use of intensive agricultural techniques threatens soil fertility and, particularly in the hilly and mountainous areas of the country, causes soil erosion. Wetlands are part of an important ecosystem that purifies polluted water but their role is also deteriorating. Because of the growing population and increasing demand for land to use for agriculture and housing, these wetlands are increasingly encroached on by illegal users; as a result, they risk losing their important environmental functions. Similar problems occur in forests where trees are illegally cut to clear land for agricultural use and grazing. Trees are also used for charcoal burning, which is a lucrative activity since most households use charcoal for cooking. The pollution of surface water is an acute environmental problem because surface water is a primary source of drinking water for a large part of the population. In addition, artisanal fishing is a main source of livelihood for people living along the shores of Lake Victoria and Lake Kyoga. Uganda is well known for its birds and its wildlife, particularly the mountain gorillas, so biodiversity must be protected for both environmental and economic reasons; these natural resources are the basis for an important source of income from tourism. Finally, NEMA points to the limited access to reliable sanitary systems, which can lead to the rapid spread of water-related diseases such as cholera and dysentery and endanger the health of the urban and rural poor in particular.

This brief summary shows that many of the main environmental problems in Uganda are simultaneously part of other policy domains, such as agriculture (erosion and soil fertility), forestry (encroachment and charcoal burning), and health (water, solid waste, and sanitation). Addressing these problems requires collaboration between environmental and natural resource management and other policy domains. As a result, the possibilities for carving out a specific domain for local environmental policy are limited because problems cannot be isolated as specifically environmental. The situation is even more complex because not all environmental problems currently fall under the responsibility of the districts. In Uganda, central control has been maintained by placing conditions on the use of centrally derived resources (Francis and James 2003). In particular, forestry and wildlife conservation still have dedicated specialized institutions under the control of central ministries. The management of most forests is therefore the responsibility of the Ugandan Forest Authority (UFA) and the protection of wildlife reserves and national parks is the task of the Uganda Wildlife Authority (UWA). Local governments only manage and control forests under 100 ha, but even in these smaller forests the UFA has a substantial influence because of its technical knowledge (Bazaara 2003).

The decentralization of natural resource management in Uganda effectively started in the late 1990s and took different forms. First, the central government delegated the coordination, monitoring and supervision of all activities related to the environment to a semi-autonomous executive agency, NEMA. Second, the government privatized some key aspects of environmental regulation. These mainly concerned the execution of environmental impact assessments and environmental impact studies, which were undertaken by developers themselves or by private consulting firms hired by these developers. Third, the central government delegated to local governments and communities the duty to manage the environment in their respective areas of jurisdiction. This last element appears to have been a largely unilateral decision made by the central government. Initially, the decentralization of environmental and natural resource management occurred through the selection of a limited number of focal districts. These districts received extensive training and support from NEMA that allowed them to experiment and show other districts how decentralized environmental management could work in practice. These first districts were later followed by others and all districts are now expected to include the protection of the environment in their development plans and to assign at least one dedicated technical staff member to be the DEO.

Under the current system, central and local governments do not always agree on who should play which role, why, and how. The country seems to have a decentralized environmental management configuration drawn by the central authorities and handed over to the different districts (LC5) for implementation and execution. Various responsibilities, including environmental management, are devolved by the center and imposed in a unilateral manner on the local governments and communities, many of whom remain reluctant to perform these tasks. The decentralization of environmental policy in Uganda therefore cannot be considered equal to "participatory" environmental governance. 
This DEO is the key local officer in charge of a large number of tasks in natural resource and environmental management at the district level (see Table 1).

Generally, this one administrative officer alone is responsible for fulfilling these tasks, although he or she is expected to collaborate with other technical staff at the district level and with the Local Environmental Committee. The DEOs have several instruments at their disposal, but their key policy tool is to link environmental objectives to the overall district development plan; this plan determines common policy goals for the district as well as budget allocations (see Table 2 for an example).

The mainstreaming of environmental and natural resource conservation must be achieved through these

Table 1 The district environmental officers' roles in natural resource and environmental management in Uganda. (From Odwedo 1996.)

1. Set long-range development goals for the district and ensure the integration of environmental action plans and concerns into the planning process at the district and local levels.

2. Act as a forum for community members to discuss and recommend environmental policies and bylaws.

3. Collect and disseminate data.

4. Coordinate activities of local environmental committees.

5. Mobilize the public to initiate and participate in environmental and natural resource management activities through self-help.

6. Ensure that the local people, NGOs, the private sector, CBOs, etc., participate in environmental planning and the implementation of environmental programs.

7. Develop district environmental action plans that incorporate subcounty (LC3) environmental action plans.

8. Prepare a district state of the environment report once every 2 years.

Table 2 Environmental policy in the Mityana district. (Presentation by the district natural resources officer of Mityana district at the NEMA workshop in Entebbe, November 17, 2008.)

As in other parts of Uganda, in the Mityana district natural resources provide the foundation for economic growth and the eradication of poverty. However, land degradation is high, the district's forest cover is diminishing, and there is increased pollution of and pressure placed on the wetland resources. To address these problems and to strengthen the local environmental management capacity, the district natural resources officer initiated the process of developing an environmental and natural resource policy. A taskforce composed of different district administrative staff was designated to formulate the policy through a participatory process.

Key challenges during the process were the absence of reliable data on the key issues identified for this policy and the effective involvement of stakeholders. One key lesson was the importance of formal engagement from other members of the staff in the taskforce. This not only helped in the identification and exploration of the issues, but also promoted the ownership of the output.

The Mityana district policy on environmental and natural resources was passed by the district council in December 2008. district development plans; securing resources from the district budget for environmental purposes requires inclusion in these plans as well. In addition to their primary tasks, DEOs may also engage in awareness-raising to inform the general population about particular environmental problems and to show what people can do themselves to solve (or prevent) them. Examples of such activities include educational projects in which school children make biodiversity inventories and develop plans to protect local wetlands (Table 3) and joint efforts with the local population to assess local waste management practices. Finally, districts may develop legislative measures or bylaws that require their citizens to follow certain guidelines for environmental protection; these guidelines may prevent (or reduce) soil erosion or offer specific prescriptions on charcoal production. Although such activities could have a positive impact at the local environmental level, as far they have been scattered and improvised.

This brief overview of environmental policy decentralization in Uganda shows that very important steps have been made in delegating certain tasks to the district authorities and in creating the local capacity to implement them. Over the years, an elaborate institutional framework for decentralized environmental policy has been developed but there are various institutional deficiencies in implementing this framework in practice. For instance, in many districts the District Environment Committees and Local Environment Committees are nonexistent or do not function well. Even where the official structures exist and function, they have problems effectively protecting the local environment. As a result, the process and practice of decentralized environmental policy in Uganda have become topics of debate. The next section further analyzes

Table 3 A case of wetland management. (From Andeweg 2006, p. 56)

The natural resources of the Oleicho wetland in Mukungoro subcounty, Kumi District, are used by fishermen, rice cultivators, cattle keepers, and domestic water users. The different interests of these groups can cause conflicts. The local community and the Kumi Sustainable Development Initiative met under the guidance of the Wetland Inspection Division to develop a management plan. This community-based wetland management plan for the years 2002-2004 focused on establishing equitable use and better management of the wetland to improve the ecological and hydrological functions of the wetland and to increase socioeconomic well-being. To ensure a fair distribution and better control of the available natural resources, the wetland is demarcated for multipurpose and wise use.

A participatory method that involved users, the local council, and religious leaders was used to plan and implement the project. Wetland committees were established with at least one person from every user group and chaired by the LC1 chairman. During the process, the communities learned how to manage the wetlands sustainably, and now, after the project has ended, the communities still maintain and apply this acquired knowledge. 
current practices in decentralized environmental policy to identify the main causes of these deficiencies.

\section{Analyzing Current Practices in Decentralized Environmental Policy}

The decentralization of environmental and natural resource management in a developing country such as Uganda involves numerous complications that are familiar to many sub-Saharan African governments. First, effective policy development and implementation are hampered by the lack of financial and human resources at the local level. In addition, different policy goals compete heavily for resources available in the district's general budget, and the environmental sector is relatively weak in this competition (see Table 4). While some areas secure resources through dedicated funding from the central government, this is not the case for environmental protection.

In addition, environmental management is still a relatively new field; few specialists are available and education on this subject lags behind other subjects. This means that qualified and motivated staff are hard to find, especially for the more remote districts. This search is even further complicated by the high turnover among DEOs. This problem seriously hampers effective local environmental policy. Below, we elaborate on some of the specific challenges that

Table 4 Struggles over limited financial resources in the Mukono district. (From Mubeezi 2007, p. 42)

\footnotetext{
After a district such as Mukono is informed about available funding from the central government, the district prepares an annual district plan before the start of the fiscal year. In the health sector, priority areas are determined by reviewing reports and meetings with subcounty and health unit committees. These meetings are supposed to bring together all stakeholders and provide planners with necessary information; however, leaders at the subcounty level acknowledged that they were left out of this procedure.

According to the town health inspector of the Mukono Town Council, environmental health service provision has been ignored in the priority setting of the district. He pointed out that since environmental health has always been a part of health in general, less explicit attention has been paid to it, particularly when compared to other health issues like the purchase of drugs. He further pointed out that when the money allocated for a specific activity is finished, this activity stops until another financial year when a new request for funding is submitted. "If, for example, we are constructing a borehole and the money needed exceeds that which was budgeted for, then that's where the work will end. We would not have anywhere else to turn." Thus, while leaders have the authority to present the needs of the communities to the district planners, their hands are tied. Money that comes to the district is generally already set for specific activities; if it is designated for the construction of a common latrine, that construction is done, even if the community needs a borehole instead.
}

complicate the decentralization of environmental policy in Uganda.

First, these challenges include tensions that emerge between the DEO and local politicians. Environmental measures may, for instance, restrict access to natural resources such as wetlands and forests and such restrictions may not be very popular among the constituencies of elected local politicians. Second, tension may arise between the different levels of government, as some decisions that are made on the national level, including those about financial matters, are implemented locally without the local authorities having had any input; this situation conflicts with the general idea of decentralized decision-making. Finally, the third challenge we want to discuss concerns the mainstreaming of environmental concerns into the broader local development policy; such mainstreaming is essential to success in a developing country where local authorities face many urgent problems, including those related to the daily survival of large numbers of poor people.

\section{Tensions Within Local Governments}

Tensions between administrative staff and politicians in the district are the consequence of the different kinds of legitimacy they invoke for their choices and decisions. Nominated technocratic and administrative personnel such as the Resident District Commissioner (RDC), the Chief Administrative Officer (CAO), and the DEO generally base their decisions on national laws and guidelines as well as on professional information, whereas local politicians (notably the District Chairperson [DCP]) are elected officials and have legitimate claims to represent their constituencies (Kabumba 2007). Unsurprisingly, elected (local) leaders are often not very inclined to enforce environmental laws when they are (expected to be) inconvenient to their voters; to do so is to risk not being re-elected. These constituencies are, for instance, not always supportive of the introduction and implementation of local environmental protection measures (Caulfield 2006) such as prohibitions on the use of wetlands or forests. Bazaara (2003) found that councilors have difficulty enacting environmental legislation or enforcing laws that would create electoral difficulties or that are not in their personal interests. In other cases, however, local councilors may receive support from their electorate to make decisions that are beneficial to the environment. See Table 5 for some positive examples.

NEMA promotes a nonpoliticized approach to environmental policymaking. The organization was established with the explicit intention of creating a neutral, technically oriented and nonpolitical institution. NEMA, and by extension also the DEOs, are expected to have the qualifications and a reasonable degree of independence to be able to avoid the constraints and difficulties of traditional 
Table 5 Popular support

Mubeezi (2007) found that there is sufficient support from citizens or community members to participate in decision-making and activities related to the provision of environmental health services in their areas. In the Mpigi District, most residents were willing to provide labor or contribute financially toward the provision of these services. This allows residents to have a sense of ownership and thus encourages them to maintain the services. In addition, according to the District Health Inspector, "Bringing environmental services near the people has made them more responsive and interested in government activities since they (are) able to follow up the different projects taking place in their area. This was earlier very difficult to do under centralized governance" (55). Likewise, in the case of wetland management, Andeweg (2006) found that the decentralization of wetland management in the Kumi and Mukono districts has empowered the people and included local knowledge and greater participation. This is said to have resulted in the integration of environmental and wetland issues into district planning and in a higher awareness among constituents about the responsibilities they have in wetland use compared to the situation 5 to 10 years ago. According to a District Technical Planning Committee member, "People have now picked an interest in wetland management." They became more aware and tend to use it more sustainably. Without decentralization "[wetland degradation] would have been much worse than it is now" (66).

bureaucracies (NEAP 1993). In reality, this focused attention to environmental matters within the work of the DEOs has to be effectuated via the deliberations of district politics. This results in the emergence of several problems. Politicians often find it difficult to manage the interrelationship between policy formulation and policy implementation, which results repeatedly in their interference with implementing measures that previously had been agreed upon by the local council. Local politicians may block the implementation of environmental measures for the protection of specific private interests. One particular complaint from the DEOs on this problem is that local politicians are regularly not trained or informed enough to understand the long-term environmental effects of their decisions. The situation is further complicated by the general lack of clarity on the difference in formal tasks between the administrative staff and local politicians; as a result, specific responsibilities remain debatable. Even when legal provisions are present and clearly defined, a power struggle may arise, particularly among the RDC, DCP and CAO; environmental issues can be caught in the middle. Whenever such a power struggle occurs, it also becomes clear that the bureaucrats are a rather heterogeneous group, with varied backgrounds, interests, and loyalties; the local politicians tend to be much more homogeneous (Kabumba 2007). If environmental problems resulting from policy measures are part of this struggle, they are not always supported equally by technical staff, whose personal loyalties may lie with their particular professional field rather than with their colleagues. The end result may be that the DEO is the only staff member defending environmental interests in a local political arena. His or her position within this arena is rather weak because it is not very attractive for local politicians to engage with environmental topics; in addition, DEOs represent limited funds and few (at least short-term) economic interests. Finally, the formal position of the DEO in the district is weak; he or she is generally a solitary civil servant in the environmental field and not a full member of the district technical planning committee, the central administrative organ at the local level.

Tensions Between the Central and the Local Levels

The second tension concerns a universal problem in processes of decentralization: Which tasks remain the responsibility of the central government and which ones become the responsibility of local authorities? The language of Uganda's environmental policy is participatory and user-focused, but in reality the policy is mediated by the legal and administrative structures and procedures established for the implementation of nationally determined measures (Brinkerhoff and Kamugasha 1998). The process is complicated because "authority and resources are captured by either (or both) central or local actors who have an interest in preventing them from reaching local governments, and/or because the design of local institutions and processes is frequently flawed" (Wunsch 2001, p. 286). In addition to a lack of clarity in dividing the formal responsibilities, financial management may add to the confusion. Decentralization in Africa has often failed, despite promising discourses, because of the overcentralization of resources, limited transfers to subnational governments, a weak local revenue base, lack of local planning capacity, limited changes in legislation and regulations, and the absence of meaningful local political process (Robinson 2007). Uganda is confronted with similar problems. In the case of wetland management, Andeweg (2006) found that local governments are responsible for planning and budgeting for wetland management activities, but the funding for these activities is allocated by the central government. In the case of environmental health, a typical local-level service provision, funding must be secured from the central government (Mubeezi 2007) (see also Table 4). The lack of fiscal decentralization is therefore felt to constrain adequate environmental and natural resource management at the local level. Over time, several changes have been made to the ways in which local authorities access the financial resources they require for the implementation of their policies. On average, nearly $90 \%$ of the total expenditures of local authorities in Uganda are funded by the central government, although the extent of this reliance varies among different districts. In his 
budget speech for fiscal year 2008-2009, the Minister of Finance, Planning and Economic Development announced a total allocation of 1.23 trillion Ugandan shillings (or 34\% of the national budget, excluding donor projects) as conditional, unconditional, or equalization grants to the local governments. In the same speech, the Minister also announced new allocation formula for the distribution of these resources since the "lack of a clear criterion...has been noted by Parliament and other stakeholders as an area of concern" (Daily Monitor, June 13, 2008). Through the abolishment of the locally collected graduated tax in 2005 and increased use of conditional grants, the central government tries to influence and restrict "choice" and political space for local authorities by attaching strong conditions and supervision procedures to the use of grants.

A related, permanent tension is the lack of a mechanism in Uganda to reconcile local authority (horizontal) and sectoral agency (vertical) responsibilities and activities; this lack undermines the coordination of resources that should lead to better environmental management. In practice, sectoral programs are financed and monitored by central ministry agencies and implemented independently from local authorities; genuine central-local partnerships that make use of the comparative advantages of local governments could enhance the planning and implementation of these programs (Romeo 2003). Specialized agencies such as the UWA and UFA constitute dedicated and centralized structures and have local staff who must work with the DEO and other local environmental institutions. However, they are national governmental staff and their loyalty remains with the central government. Moreover, the DEOs and other local institutions have more diverse interests than the specialized goals of wildlife protection or forest conservation espoused by the UWA and UFA, respectively.

For instance, the legal provisions for wildlife or forest protection are not clearly detailed and the relevant legal and policy frameworks are disjointed; this situation results in many conflicts and the loss of forest- and wildlife-related resources. Decentralization in the forestry sector has contributed to greater inefficiency, as the transfer of powers is mired in a confusing array of legal and policy changes. The national government ultimately retained significant powers over the management of forests and wildlife while selectively "decentralizing" limited powers to district and subcounty councils. Over time, power shifted both downward and upward, with the Forest Department regaining control of the coveted and larger central forest reserves in 1998. This unsteady progression of decentralization reform points to an unwillingness to transfer significant, discretionary powers over the management and use of forest reserves and wildlife to the district and subcounty councils (Muhereza 2003). A striking example of this reluctance is the presidential interference in the protection of the Mabira Forest reserve in 2006; 70 of the $300 \mathrm{~km}^{2}$ of protected forest was to be allocated to a sugarcane plantation. Only after national and international protest was the plan (temporarily?) suspended (BBC 2007a, b).

Natural resources are officially managed for the benefit of the people of Uganda. Local communities should be central actors in the management of local resources and they should also benefit from such resources. For example, in the Bwindi Impenetrable National Forest the central government, represented by the UWA, has devolved decision-making to the local institutions. Cases or offenses that are deemed to be "not critical" by the UWA (including crop raids by wildlife, which many communities would definitely define as a "grave" offense against them) can be dealt with by local institutions or communities. However, the Wildlife Statute and Policy already rules out the possibility of compensation cases on crop damage, thus limiting the options available to address this problem. The cases that the UWA defines as serious (the killing of wildlife or cutting of big trees) can only be handled by the UWA itself and the police. In other words, the decisions to be made in "important" cases cannot be entrusted to local communities and the UWA's definition of the gravity of the offense matters more than the communities' own definitions (Namara and Nsabagasani 2003).

\section{Mainstreaming Environmental Policy}

A third tension in the decentralization process in Uganda concerns the official objective of mainstreaming environmental policy. Environmental and natural resource management is supposed to be connected with and possibly integrated into other policy domains at the local level; these domains include health, education, and economic and infrastructure development. Achieving this goal requires coherent policies and strategies as well as competition for limited financial resources. In practice, however, mainstreaming environmental protection involves a number of challenges. First, it is hard to convince technical and administrative staff working on other policy issues of the importance of environmental problems and the need to address them collectively. Second, it is challenging to identify priorities and adequate measures in a district development policy in such a way that it does not make environmental protection disappear behind other policy goals. Overcoming these challenges is problematic as districts generally have entrenched processes of planning and conducting development activities. They tend to take a strongly sectoral approach to planning and thereby exhibit a bias toward social service (health and education) provisions. This makes it difficult to effectively integrate crosscutting issues such as the protection of environmental 
and natural resources (Brinkerhoff and Kamugasha 1998). Some DEOs respond by underlining the economic importance of environmental and natural resource management to increase interest among other administrative staff and local politicians. They do this by stressing the relevance of cost-benefit calculations and seeking ways to generate monetary income from environmental protection activities, such as payment for environmental services and earnings from carbon credits. However, so far these attempts have not yielded significant results, and it is difficult to translate general principles into concrete material resources for environmental policy.

In sum, the decentralization of environmental and natural resource management in Uganda has been confronted with a series of different structural problems over the last decade. Tensions between civil servants and local politicians and between central and decentralized levels of government and the challenges of mainstreaming environmental protection have all complicated the decentralization process. The question, then, is whether decentralization should be abandoned altogether as an achievable aim or whether some perspectives remain after drawing lessons from these experiences.

\section{Discussion and Conclusions}

It has been nearly 20 years since decentralization reforms began in Uganda and more than 10 years since environmental and natural resource management was included in these reforms. There remains a widespread consensus on the desirability of this political transformation process (Andeweg 2006). Decentralization in general has yielded several positive results, including improvements in service delivery as well as increased political participation and more downward accountability by local politicians. Some do suggest that the level of participation must be further strengthened (Bazaara 2003). However, in the environmental domain, the achievements-both in the extent of local participation and accountability and in the social and environmental outcomes - seem to be limited and to vary across districts. Despite these limited results, one should not fall into the trap of considering the decentralization process itself to be responsible for these failures and therefore suggesting that a centralized approach would perform better (Büscher and Dressler 2007). This limited impact can be explained as the result of the insufficient capacity (in terms of both knowledge and financial means) of the DEOs. In addition, it is difficult to build working local institutions that can provide complex and technically demanding services under the conditions of scarcity and general turbulence that prevail in Uganda. Variations in environmental performance between different districts are mostly explained by the permanent growth in the number of districts, which creates disturbances by requiring repeated reorganization.

However, without ignoring the reality of these problems, they seem to insufficiently capture some of the more structural dynamics involved. In Uganda, a great deal of energy has been devoted to strengthening local capacity for environmental and natural resource management through training and focused support for elected officials and administrative staff. However, local environmental management cannot be reduced to the individual qualities of local actors. In many situations, environmental governance outcomes depend less on the personal motivations and qualities of the local councilors and administrators and more on the incentives created by the institutional environment in which they have to operate (Romeo 2003). Instead of focusing on the individual level (as do many socalled capacity building projects), two other levels should be emphasized: the institutional level, where government structures arrange local environmental management; and the systemic level, where the policy and legal frameworks direct local environmental policy.

Many districts saw a tension between nominated technical staff and elected local politicians. This problem will not disappear by increasing the district environmental staff capacity, although training may be beneficial if it is combined with improved communication with politicians. There is a structural tension in the decentralization process between the goal of increasing efficiency and effectiveness and the objective of increased local democracy, participation, and equity promotion (Robinson 2007). It is essential to acknowledge that many environmental problems are not simply technical and nonpolitical. As a result, environmental policy involves difficult decision-making and the need to balance competing interests. Because offsets between different choices are necessary and result in winners and losers among the local stakeholders, environmental and natural resource management should be considered part of the political decision-making process. The need to address the inevitable conflicts that result from environmental measures should be incorporated into the institutional framework in a more consistent manner.

Furthermore, it is essential to clarify the responsibilities of national specialized natural protection agencies in Uganda such as the UWA and UFA, particularly since they have a parallel presence at the local level. These specialized institutions have many more material and human resources than the districts and they directly control important natural resources at the local level; however, they lack local political support and feel no need to coordinate with other interests. This situation understandably leads to conflicts between different (groups of) local actors, which should be solved by clearly dividing responsibilities and requiring specialized agencies to integrate their 
activities into a coherent local environmental and natural resource management policy.

Mainstreaming environmental and natural resource management with other policy domains at the local level requires the design of a local strategy for sustainable development. Successful integration requires the recognition of environmental concerns as key elements in development and not as luxuries that can be discarded whenever economic or social concerns demand it. The importance of environmental protection to the livelihood of local communities, including the poor, should be emphasized and made concrete. By promoting adequate policy measures, environmental governance can be more successfully mainstreamed into local development plans.

Finally, decentralization is a dynamic political process that will probably never be finished; new subjects will arise, scientific or technological innovations will change optimal policy solutions, and political priorities may promote interventions through other levels of government. Moreover, negotiations about the distribution of responsibilities and the respective duties of various administrative levels will continue. Decentralizing environmental policy in Uganda is a process in which any successful set of administrative reforms must be reconciled with the broader political and economic context where economic growth is necessary for financing administrative improvements (Harrison 2001). In this process, particular attention should be focused on securing the decentralization of significant power, especially power over finances (Conyers 2007). Foreign donors should be willing to engage in the same approach, but currently international aid programs seem to move away from project-based interventions (which allow local government support) toward budget support; this shifts decisions back to the center (Mitchinson 2003). If donors seriously want to promote the decentralization of environmental and natural resource management, they should allow funds to be transferred to the district level without imposing detailed conditions on their use; they must allow local authorities to decide how best to use these resources.

Acknowledgments This article was based on research done within the framework of the EMCaB-U project (Environmental Management Capacity Building-Uganda), funded by NUFFIC in The Netherlands. The authors would like to thank NEMA-Uganda, in particular, Beatrice Adimola and M.Sc. students Karin Andeweg and Ruth Mubeezi, for their input.

Open Access This article is distributed under the terms of the Creative Commons Attribution Noncommercial License which permits any noncommercial use, distribution, and reproduction in any medium, provided the original author(s) and source are credited.

\section{References}

Agrawal A, Gibson CC (1999) Enchantment and disenchantment: the role of community in natural resource conservation. World Development 27:629-649

Andeweg K (2006) Central issues in decentralised wetland management, a comparative case study in Kumi and Mukono district, Uganda. MSc thesis, Environmental Policy Group, Wageningen University

Bazaara N (2003) Decentralization, politics and environment in Uganda. WRI-Environmental Governance in Africa Working Papers, Washington, DC

BBC (2007a) BBC News, 17 April 2007. Available at: http://news.bbc. co.uk/2/hi/africa/6551905.stm. Accessed 18 Dec 2008

BBC (2007b) BBC News, 22 May 2007. Available at: http://news.bbc. co.uk/2/hi/africa/6680637.stm. Accessed 18 Dec 2008

Berkhout S (2005) The decentralisation debate: thinking about power. Review of Education 51:313-327

Blaikie P (2006) Is small really beautiful? Community-based natural resource management in Malawi and Botswana. World Development 34:1942-1957

Brinkerhoff DW, Kamugasha BN (1998) Uganda and the national environmental action plan: focusing on implementation. USAID, Washington, DC

Büscher B, Dressler W (2007) Linking neoprotectionism and environmental governance: on the rapidly increasing tensions between actors in the environment-development nexus. Conservation and Society 5:586-611

Caulfield JL (2006) The politics of bureau reform in sub-Saharan Africa. Public Administration and Development 26:15-26

Conyers D (2007) Decentralisation and service delivery: lessons from sub-Saharan Africa. IDS Bulletin 38:18-32

Dressler WH, Kull CA, Meredith TC (2006) The politics of decentralizing national parks management in the Philippines. Political Geography 25:789-816

Foucault M (1977) Discipline and punish: the birth of the prison. Penguin, London

Francis P, James R (2003) Balancing rural poverty reduction and citizen participation: the contradictions of Uganda's decentralization program. World Development 31:325-337

Harrison G (2001) Post-conditionality politics and administrative reform: reflections on the cases of Uganda and Tanzania. Development and Change 32:657-679

Iversen V, Fjeldstad OH, Bahiigwa G, Ellis F, James R (2006) Private tax collection-remnant of the past or a way forward? Evidence from rural Uganda. Public Administration and Development 26: $317-328$

Kabumba I (2007) Conflicts between elected and appointed officials in districts. In: Asiimwe D, Musisi NB (eds) Decentralisation and transformation of governance in Uganda. Fountain, Kampala, pp 28-40

Kiragu K (2002) Improving service delivery through public service reform: lessons of experience from select sub-Saharan Africa countries. OECD, Nairobi

Kisembo SW (2006) Handbook on decentralisation in Uganda. Fountain, Kampala

Lane MB, McDonald G (2005) Community-based environmental planning: operational dilemmas, planning principles and possible remedies. Journal of Environmental Policy and Management 48: 709-731

Larson AM, Soto F (2008) Decentralization of natural resource governance regimes. Annual Review of Environment and Resources 33:213-239 
Mehta P (1996) Local Agenda 21; practical experiences and issues emerging from the South. Environmental Impact Assessment Review 16:309-320

Ministry of Natural Resources (MNR) (1994) The national environment management policy for Uganda. Government of Uganda, Kampala

Mitchinson R (2003) Devolution in Uganda: an experiment in local service delivery. Public Administration and Development 23: 241-248

Mubeezi R (2007) Decentralization of environmental health services in Uganda, a case study of Mpigi and Mukono districts. MSc thesis, Environmental Policy Group, Wageningen University

Muhereza FE (2003) Commerce, kings and local government in Uganda; decentralizing natural resources to consolidate the state. WRI-Environmental Governance in Africa Working Papers, Washington, DC

Namara A, Nsabagasani X (2003) Decentralization and wildlife management: devolving rights or shedding responsibility? Bwindi Impenatrable Natural Park, Uganda. WRI-Environmental Governance in Africa Working Papers, Washington, DC

National Environmental Action Plan (NEAP) (1993) Environmental policy, legislation and institutional arrangements. NEAP, Kampala

National Environmental Management Authority (NEMA) (2007) State of the environment; report for Uganda 2006/2007. NEMA, Kampala

Nsibambi A (1998) Introduction. In: Nsibambi A (ed) Decentralisation and civil society in Uganda; the quest for good governance. Fountain, Kampala, pp 1-11

Odwedo M (1995) Decentralisation of natural resource management and the role of the district as planning unit. Speech by the undersecretary of the Ministry of Local Government at the
Mbale District environmental profile workshop Mbale, Ministry of Local Government, Kampala

Odwedo M (1996) Decentralisation of natural resources and environmental management in Uganda: the concept and the way forward. NEMA, Kampala

Polidano C, Hulme D (1999) Public management reform in developing countries: issues and outcomes. Public Management Review 1:121-132

Republic of Uganda (2008) Budget speech, Minister of Finance, Planning and Economic Development, financial year 2008/09. 12 June 2008, Kampala

Ribot JC (2002) Democratic decentralization of natural resources; institutionalizing popular participation. WRI, Washington, DC

Robinson M (2007) Does decentralisation improve equity and efficiency in public service delivery provision? IDS Bulletin 38:7-17

Romeo LG (2003) The role of external assistance in supporting decentralization reform. Public Administration and Development 23:89-96

United Nations Environmental Program (UNEP) (2002) Africa environmental outlook; past, present and future perspectives. UNEP, Nairobi

Wetaaka Wadala A (2007) The politics of decentralisation in Uganda. In: Asiimwe D, Musisi NB (eds) Decentralisation and transformation of governance in Uganda. Fountain, Kampala, pp 41-60

Woodhouse P (1997) Governance \& local environmental management in Africa. Review of African Political Economy 24:537547

Wunsch JS (2001) Decentralization, local governance and 'recentralization' in Africa. Public Administration and Development $21: 277-288$ 